\title{
Hipertensão e Condições Clínicas Associadas
}

Coordenador:

Sebastião Ferreira Filho (MG)

\section{Secretário:}

Rogério Baumgratz de

Paula (MG)

\section{Participantes:}

Álvaro Avezum (SP)

Gabriel R. de Freitas (SP) - ABN

Emílio Francischetti (RJ)

Marcelo Batista (SP)

Maria Helena Catelli

Carvalho (SP)

Maria Tereza Zanella (SP)

Marília de Brito Gomes

(RJ) - SBD

Maurício Wajngarten (SP)

Nilson Roberto de Melo

(SP) - FEBRASGO

Otávio Rizzi Coelho (SP)

Ricardo M. da Rocha

Meirelles (SP) - SBEM

Roberto Miranda (SP)

Rosangela Milagres (MG)

\section{Diabetes Melito}

A medida da PA no consultório em pacientes com diabetes melito (DM) deve ser feita nas posições supina e ortostática em função da maior ocorrência de hipotensão ortostática ${ }^{1}(\mathrm{C} 4)$. Por se tratar de pacientes de alto risco para eventos cardiovasculares, as metas a serem atingidas devem ser 130/80 $\mathrm{mmHg}^{2,3}$ (A1). Estudos demonstraram não haver benefícios adicionais com redução da PA, em diabéticos, inferior a esses valores $^{4}$ (A1). A avaliação inicial pode ser estabelecida por meio da medição em duplicata da razão albumina/creatinina em amostra de urina isolada (micrograma/mg de creatinina) considerando-se normais valores menores que 30 e microalbuminúria aqueles entre 30 e $299 \mathrm{mg}$. Valores maiores que $300 \mathrm{mg}$ estabelecem o diagnóstico de macroproteinúria e determinam propensão adicional ao desenvolvimento de doença renal crônica ${ }^{5}$ (A1). Todos os agentes antihipertensivos podem ser utilizados, sendo que na maioria das vezes dois ou mais deles precisam ser associados para que os objetivos do tratamento sejam atingidos. Existem vantagens no uso de bloqueadores do SRAA e na associação destes com um antagonista dos canais de cálcio ${ }^{6-11}$ $(\mathrm{A} 1, \mathrm{~B} 2)$. A associação de IECA com BRA II já se mostrou eficiente para promover maior redução da proteinúria ${ }^{10}$ (A1). Mais recentemente, a associação do inibidor direto da renina, alisquireno, com o BRA II losartan também resultou em redução adicional da albuminúria em pacientes com nefropatia diabética ${ }^{12}$ (A1). Nos casos de hipotensão postural, a escolha da medicação anti-hipertensiva e o ajuste das doses a serem utilizadas devem levar em conta a hora do dia e a posição do paciente no momento da medida da PA. Elevação da cabeceira da cama e uso de agentes que aumentem o volume plasmático, como a fludrocortisona e o domperidone, constituem alternativas para evitar a hipotensão matutina e a consequente hipertensão vespertina e noturna ${ }^{13}(\mathrm{C} 4)$.

\section{Síndrome Metabólica (SM)}

O diagnóstico de SM identifica indivíduos com quadro cardiometabólico extremamente adverso, que apresentam aumento significativo do risco cardiovascular e que necessitarão de intervenção agressiva para cada fator de risco específico ${ }^{14}(\mathrm{~A} 1)$. Devido a sua associação frequente com a obesidade, a abordagem da HAS nesses indivíduos deve ser considerada em conjunto com o tratamento da hipertensão no indivíduo obeso.

\section{Obesidade e Síndrome Metabólica}

\section{REDUÇÃO dO PESO}

A redução do peso corporal contribui para o controle da PA de forma consistente e significativa. Em metanálise publicada em 2008, que avaliou 38 estudos controlados e randomizados, registrou-se diminuição da média da PA de 6,3/3,4 mmHg associada à perda de peso ${ }^{15}$ (A1).

\section{ANTI-HIPERTENSIVOS}

O uso de diuréticos tiazídicos em baixas doses deve ser o tratamento medicamentoso inicial preferido. IECA, BRA II e ACC podem ser usados com segurança, isoladamente ou em associações. Deve-se enfatizar que mudanças no estilo de vida constituem as medidas mais eficazes para a prevenção e para o tratamento da HAS, contribuindo para a redução do risco cardiovascular. 


\section{Doença Renal Crônica (DRC)}

DOENÇA RENAL CRÔNICA ESTÁGIOS 1 E 2

Em estágios iniciais da DRC, o controle da PA parece constituir a medida mais eficaz para a prevenção de progressão do dano renal, independentemente da classe da medicação anti-hipertensiva utilizada. No entanto, nos pacientes com perda proteica preconizase o bloqueio do SRAA, visando à redução da hipertensão intraglomerular e à diminuição da excreção urinária de proteínas.

\section{Doença RENAL CRÔNICA ESTÁGIOS 3, 4 E 5 (NÃO DIA- LÍTICA)}

Tanto os IECAs quantos os BRAs têm comprovada eficácia, muitas vezes ultrapassando os benefícios gerados pela redução da pressão arterial per $e^{16}$ (A1). Sua eficácia na nefroproteção é maior em pacientes com perda proteica ${ }^{11}$ (A1). Publicações recentes, em hipertensos primários, mostram que o duplo bloqueio do SRAA em diferentes versões resultou em maior redução da pressão arterial quando comparado com monoterapia equivalente ${ }^{17,18}(\mathrm{~B} 2)$. Uma publicação ${ }^{19}$ (B2) colocou o bloqueio vigoroso do SRAA, por meio da combinação IECA e BRA, "sob suspeita", já que, apesar do bloqueio duplo comparado com a monoterapia ter resultado em maior redução da PA, a esperada diminuição de eventos cardiovasculares não ocorreu. Além disso, a associação provocou maior queda da função renal, apesar de maior redução da microalbuminúria e, ainda, número superior de eventos adversos em comparação com monoterapia. Deste modo, o duplo boqueio do SRAA não está indicado para pacientes portadores de DRC sem perda proteica ou com microalbuminúria. No que tange ao uso de inibidores diretos da renina observou-se redução significativa da proteinúria em diabéticos quando se associou alisquireno a losartana ${ }^{20}$ (A1). Do mesmo modo, estudos iniciais em humanos têm demonstrado redução da proteinúria com o uso de bloqueadores da aldosterona $^{21}$ (B2). Normalmente, os diuréticos tiazídicos são mais eficazes em pacientes nos estágios 1,2 e 3 da DRC, enquanto os diuréticos de alça são preconizados para os estágios 4 e 5 . Comprovadamente, os diuréticos reduzem a morbidade e mortalidade cardiovascular ${ }^{22,23}$ (A1) e são a segunda opção para o tratamento da hipertensão na DRC, especialmente quando combinados com IECA ou BRA (B2). Para atingir as metas de PA em pacientes com DRC, em geral é necessária a combinação de três ou mais antihipertensivos, em doses plenas ${ }^{24}$ (A1). Assim, os $\mathrm{ACC}^{25,26}$ (A1) são indicados como terceira opção e seu uso combinado com IECA se associou a maior redução de eventos $\mathrm{CV}^{9}$ (B2). Outras opções incluem os betabloqueadores, os inibidores adrenérgicos de ação central e, eventualmente, os vasodilatadores de ação direta como o minoxidil e a hidralazina.

\section{Doença RENAL CRÔNICA ESTÁGIO 5 EM PROGRAMA dE} DIÁLISE

O controle da hipervolemia, a investigação de coronariopatia e da disfunção ventricular e a identificação de arritmias constituem estratégias para a abordagem terapêutica nestes pacientes.

\section{TRANSPLANTADOS RENAIS}

Os ACC constituem a primeira escolha para o tratamento da HAS em pacientes transplantados ${ }^{27}$ (A1). Pacientes em uso de ciclosporina apresentam vasoconstrição arteriolar, que pode ser revertida pelo uso de $\mathrm{ACC}^{28}$ (C4). Nos transplantados, há evidências de que os medicamentos que bloqueiam o SRAA podem melhorar os resultados do transplante ${ }^{29}$ (B2). Os diuréticos são medicamentos que podem ser prescritos no controle da HAS de pacientes submetidos a transplante renal, mas o seu uso requer monitorização cuidadosa dos eletrólitos séricos e da função renal. ${ }^{30}$

\section{Doença Arterial Coronariana}

Está claramente demonstrada a associação entre HAS e doença arterial coronariana (DAC), independentemente da idade. A redução adequada da PA é fundamental para a prevenção de eventos relacionados à DAC, a despeito do grupo de medicamentos antihipertensivos utilizados ${ }^{31,32}$ (A1), objetivando-se metas de PA de $130 \times 80 \mathrm{mmHg}^{31,32}$ (A1). Especula-se sobre a possibilidade de a redução excessiva da PA diastólica (PAD) aumentar esse risco, configurando a chamada curva J. ${ }^{33} \mathrm{Em}$ pacientes idosos ou diabéticos com DAC obstrutiva e evidência de isquemia, parece mais adequado reduzir a PAD lentamente e evitar valores muito baixos. Há controversias sobre até que nível reduzir a PAD sem problemas ${ }^{32}(\mathrm{C} 2)$. Os betabloqueadores devem ser utilizados nos pacientes com angina ou com infarto do miocárdio prévio, exceto se houver contraindicação formal ${ }^{34}$ (A1). Os IECA e os BRA II estão indicados para a prevenção primária em pacientes de alto risco cardiovascular, em hipertensos com DAC estável ou com infarto do miocárdio prévio $^{35,36}$ (A1). Os diuréticos tiazídicos demonstraram proteção contra eventos coronarianos em estudos randomizados em prevenção primária ${ }^{37-39}$ (A1). Os bloqueadores dos canais lentos do cálcio também 
demonstraram prevenção de eventos coronários ${ }^{40,41}$ (A1) e podem ser utilizados como alternativa aos betabloqueadores para o tratamento da angina, porém não são recomendados para prevenção secundária.

\section{Acidente Vascular Encefálico}

O tratamento anti-hipertensivo está associado a uma redução de $35 \%$ a $44 \%$ na incidência de acidente vascular encefálico $(\mathrm{AVE})^{42}(\mathrm{~A} 1)$.

\section{ACIDENTE VASCULAR ENCEFÁLICO ISQUÊMICO}

Uma resposta hipertensiva aguda ocorre em cerca de $80 \%$ dos pacientes nas primeiras 48 horas após o AVE isquêmico ${ }^{43}$ (A1), reduzindo espontaneamente em algumas semanas após o evento. Estudos mostram que os BRA II previnem a recorrência de eventos vasculares em pacientes com AVE do tipo isquêmico ${ }^{44}$ (A1) enquanto outros relatam que o tratamento com labetolol ou lisinopril reduziu a mortalidade aos 90 dias, em comparação com placebo em portadores de AVE isquêmico ou hemorrágico ${ }^{45}$ (A1). $\mathrm{Na}$ ausência de evidências de ensaios clínicos, as diretrizes atuais sugerem que a PA não deve ser reduzida na fase aguda do AVE isquêmico, a não ser quando a PA sistólica estiver em torno dos $200 \mathrm{mmHg}$ e a PA diastólica, superior a $120 \mathrm{mmHg}$, ou, ainda, na presença de complicações em outros órgãos (C4). Nos pacientes candidatos a tratamento trombolítico, a PA sistólica deve ser reduzida para valores abaixo de $185 \mathrm{mmHg}$ e a PA diastólica para valores inferiores a $110 \mathrm{mmHg}$ antes da infusão do trombolítico e mantidas nessa faixa nas primeiras 24 horas após a realização da trombólise $e^{46,47}$ (B2).

\section{HeMorRagia INTRACEREBRAL}

Estudos observacionais sugerem que a HAS está relacionada com a expansão do hematoma nas primeiras 24 horas $^{48}$ (B). O crescimento do hematoma foi menor no grupo de pacientes cuja PA sistólica-alvo foi de $140 \mathrm{mmHg}$ do que no grupo cujo alvo foi de $180 \mathrm{mmHg}$, embora após a correção para o tamanho inicial do hematoma a diferença não tenha sido estatisticamente significante. ${ }^{48,49}$ As diretrizes atuais sugerem PA da ordem de $160 \times 90 \mathrm{mmHg}^{50,51}(\mathrm{C})$.

\section{REFERÊNCIAS}

1. Freeman R. Clinical practice. Neurogenic orthostatic hypotension. N Engl J Med 2008; 358(6):615-624.

2. Patel A, MacMahon S, Chalmers J et al. Effects of a fixed combination of perindopril and indapamide on macrovascular and micro-vascular outcomes in patients with type 2 diabetes mellitus (the ADVANCE trial): a randomised controlled trial. Lancet 2007; 370(9590):829-840.

3. The sixth report of the Joint National Committee on Prevention, Detection, Evaluation, and Treatment of High Blood Pressure. Arch Intern Med 1997; 157(21):2413-2446.

4. ACCORD Study Group, Cushman WC, Evans GW, Byington RP et al. Effects of intensive blood-pressure control in type 2 diabetes mellitus. $\mathrm{N}$ Engl J Med 2010, 362(17):1575-1585.

5. Gall MA, Hougaard P, Borch-Johnsen K, Parving HH. Risk factors for development of incipient and overt diabetic nephropathy in patients with non-insulin dependent diabetes mellitus: prospective, observational study. BMJ 1997; 314(7083):783-788.

6. Yusuf S, Gerstein H, Hoogwerf B et al. Ramipril and the development of diabetes. JAMA 2001; 286(15):1882-1885.

7. Dahlof B, Devereux RB, Kjeldsen SE et al. Cardiovascular morbidity and mortality in the Losartan Intervention For Endpoint reduction in hypertension study (LIFE): a randomised trial against atenolol. Lancet 2002; 359(9311):995-1003.

8. Yusuf S, Teo KK, Pogue J, Dyal L, Copland I, Schumacher $\mathrm{H}$, et al. Telmisartan, ramipril, or both in patients at high risk for vascular events. $\mathrm{N}$ Engl J Med 2008; 358(15):1547-1559.

9. Jamerson K, Weber MA, Bakris GL et al. Benazepril plus amlodipine or hydrochlorothiazide for hypertension in high-risk patients. N Engl J Med 2008; 359(23):2417-2428.

10. Atkins RC, Briganti EM, Lewis JB et al. Proteinuria reduction and progression to renal failure in patients with type 2 diabetes mellitus and overt nephropathy. Am J Kidney Dis 2005; 45(2):281-287.

11. de ZD, Remuzzi G, Parving $\mathrm{HH}$ et al. Proteinuria, a target for renoprotection in patients with type 2 diabetic nephropathy: lessons from RENAAL. Kidney Int 2004; 65(6):2309-2320.

12. Parving HH, Persson F, Lewis JB, Lewis EJ, Hollenberg NK. Aliskiren combined with losartan in type 2 diabetes and nephropathy. N Engl J Med 2008; 358(23):2433-2446.

13. Lopes de Faria SR, Zanella MT, Andriolo A, Ribeiro AB, Chacra AR. Peripheral dopaminergic blockade for the treatment of diabetic orthostatic hypotension. Clin Pharmacol Ther 1988; 44(6):670-674.

14. Lakka HM, Laaksonen DE, Lakka TA et al. The metabolic syndrome and total and cardiovascular disease mortality in middle-aged men. JAMA 2002; 288(21):2709-2716.

15. Horvath K, Jeitler K, Siering U et al. Long-term effects of weight-reducing interventions in hypertensive patients: systematic review and meta-analysis. Arch Intern Med 2008; 168(6):571-580.

16. Lewis EJ, Hunsicker LG, Clarke WR et al. Renoprotective effect of the angiotensin-receptor antagonist irbesartan in patients with nephropathy due to type 2 diabetes. N Engl J Med 2001; 345(12):851-860.

17. Geiger H, Barranco E, Gorostidi $\mathrm{M}$ et al. Combination therapy with various combinations of aliskiren, 
valsartan, and hydrochlorothiazide in hypertensive patients not adequately responsive to hydrochlorothiazide alone. J Clin Hypertens (Greenwich) 2009; 11(6):324-332.

18. Scaglione R, Argano C, Di CT et al. Effect of dual blockade of renin-angiotensin system on TGFbeta 1 and left ventricular structure and function in hypertensive patients. J Hum Hypertens 2007; 21(4):307-315.

19. Mann JF, Schmieder RE, McQueen M et al. Renal outcomes with telmisartan, ramipril, or both, in people at high vascular risk (the ONTARGET study): a multicentre, randomised, double-blind, controlled trial. Lancet 2008; 372(9638):547-553.

20. Parving HH, Brenner BM, McMurray JJ et al. Aliskiren Trial in Type 2 Diabetes Using Cardio-Renal Endpoints (ALTITUDE): rationale and study design. Nephrol Dial Transplant 2009; 24(5):1663-1671.

21. Sato A, Hayashi K, Naruse M, Saruta T. Effectiveness of aldosterone blockade in patients with diabetic nephropathy. Hypertension 2003; 41(1):64-68.

22. Psaty BM, Smith NL, Siscovick DS et al. Health outcomes associated with antihypertensive therapies used as first-line agents. A systematic review and meta-analysis. JAMA 1997; 277(9):739-745.

23. Prevention of stroke by antihypertensive drug treatment in older persons with isolated systolic hypertension. Final results of the Systolic Hypertension in the Elderly Program (SHEP). SHEP Cooperative Research Group. JAMA 1991; 265(24):3255- 3264.

24. Plantinga LC, Miller ER, III, Stevens LA et al. Blood pressure control among persons without and with chronic kidney disease: US trends and risk factors 1999-2006. Hypertension 2009; 54(1):47-56.

25. Hansson L, Hedner T, Lund-Johansen P, Kjeldsen SE, Lindholm LH, Syvertsen JO, et al. Randomised trial of effects of calcium antagonists compared with diuretics and beta-blockers on cardiovascular morbidity and mortality in hypertension: the Nordic Diltiazem (NORDIL) study. Lancet 2000; 356(9227):359-365.

26. Dahlof B, Sever PS, Poulter NR et al. Prevention of cardiovascular events with an antihypertensive regimen of amlodipine adding perindopril as required versus atenolol adding bendroflumethiazide as required, in the Anglo-Scandinavian Cardiac Outcomes Trial-Blood Pressure Lowering Arm (ASCOT-BPLA): a multicentre randomised controlled trial. Lancet 2005; 366(9489):895-906.

27. Cross NB, Webster AC, Masson P, O'Connell PJ, Craig JC. Antihypertensives for kidney transplant recipients: systematic review and meta-analysis of randomized controlled trials. Transplantation 2009; 88(1):7-18.

28. Venkat-Raman G, Feehally J, Elliott HL et al. Renal and haemodynamic effects of amlodipine and nifedipine in hypertensive renal transplant recipients. Nephrol Dial Transplant 1998; 13(10):2612-2616.

29. Hernandez D, Lacalzada J, Salido E et al. Regression of left ventricular hypertrophy by lisinopril after renal transplantation: role of ACE gene polymorphism. Kidney Int 2000; 58(2):889-897.

30. Weir MR. Blood pressure management in the kidney transplant recipient. Adv Chronic Kidney Dis 2004; 11(2):172-183.
31. Sipahi I, Tuzcu EM, Schoenhagen P et al. Effects of normal, pre-hypertensive, and hypertensive blood pressure levels on progression of coronary atherosclerosis. J Am Coll Cardiol 2006; 48(4):833-838.

32. Rosendorff C, Black HR, Cannon CP et al. Treatment of hypertension in the prevention and management of ischemic heart disease: a scientific statement from the American Heart Association Council for High Blood Pressure Research and the Councils on Clinical Cardiology and Epidemiology and Prevention. Circulation 2007; 115(21):2761-2788.

33. Cruickshank JM, Thorp JM, Zacharias FJ. Benefits and potential harm of lowering high blood pressure. Lancet 1987; 1(8533):581-584.

34. Bangalore S, Messerli FH, Kostis JB, Pepine CJ. Cardiovascular protection using beta-blockers: a critical review of the evidence. J Am Coll Cardiol 2007; 50(7):563-572.

35. Yusuf S, Sleight P, Pogue J, Bosch J, Davies R, Dagenais G. Effects of an angiotensin-convertingenzyme inhibitor, ramipril, on cardiovascular events in high-risk patients. The Heart Outcomes Prevention Evaluation Study Investigators. N Engl J Med 2000; 342(3):145-153.

36. Major outcomes in high-risk hypertensive patients randomized to angiotensin-converting enzyme inhibitor or calcium channel blocker $v s$ diuretic: The Antihypertensive and Lipid-Lowering Treatment to Prevent Heart Attack Trial (ALLHAT). JAMA 2002; 288(23):2981-2997.

37. Mochizuki S, Dahlof B, Shimizu M et al. Valsartan in a Japanese population with hypertension and other cardiovascular disease (Jikei Heart Study): a randomised, open-label, blinded endpoint morbidity-mortality study. Lancet 2007; 369(9571):1431-1439.

38. Pfeffer MA, McMurray JJ, Velazquez EJ et al. Valsartan, captopril, or both in myocardial infarction complicated by heart failure, left ventricular dysfunction, or both. N Engl J Med 2003; 349(20):1893-1906.

39. Julius S, Kjeldsen SE, Weber M et al. Outcomes in hypertensive patients at high cardiovascular risk treated with regimens based on valsartan or amlodipine: the VALUE randomised trial. Lancet 2004; 363(9426):2022-2031.

40. Pepine CJ, Handberg EM, Cooper-DeHoff RM et al. A calcium antagonist vs a non-calcium antagonist hypertension treatment strategy for patients with coronary artery disease. The International VerapamilTrandolapril Study (INVEST): a randomized controlled trial. JAMA 2003; 290(21):2805-2816.

41. Hansson L, Hedner T, Lund-Johansen $\mathrm{P}$ et al. Randomised trial of effects of calcium antagonists compared with diuretics and beta-blockers on cardiovascular morbidity and mortality in hypertension: the Nordic Diltiazem (NORDIL) study. Lancet 2000; 356(9227):359-365.

42. Goldstein LB, Adams R, Alberts MJ et al. Primary prevention of ischemic stroke: a guideline from the American Heart Association/American Stroke Association Stroke Council: cosponsored by the Atherosclerotic Peripheral Vascular Disease Interdisciplinary Working Group; Cardiovascular Nursing Council; Clinical Cardiology Council; 
Nutrition, Physical Activity, and Metabolism Council; and the Quality of Care and Outcomes Research Interdisciplinary Working Group: the American Academy of Neurology affirms the value of this guideline. Stroke 2006; 37(6):1583-1633.

43. Leonardi-Bee J, Bath PM, Phillips SJ, Sandercock PA. Blood pressure and clinical outcomes in the International Stroke Trial. Stroke 2002; 33(5):1315-1320.

44. Schrader J, Luders S, Kulschewski A et al. The ACCESS Study: evaluation of Acute Candesartan Cilexetil Therapy in Stroke Survivors. Stroke 2003; 34(7):1699-1703.

45. Potter JF, Robinson TG, Ford GA et al. Controlling hypertension and hypotension immediately poststroke (CHHIPS): a randomised, placebo-controlled, double-blind pilot trial. Lancet Neurol 2009; $8(1): 48-56$.

46. Adams HP, Jr., del ZG, Alberts MJ et al. Guidelines for the early management of adults with ischemic stroke: a guideline from the American Heart Association/ American Stroke Association Stroke Council, Clinical Cardiology Council, Cardiovascular Radiology and Intervention Council, and the Atherosclerotic Peripheral Vascular Disease and Quality of Care Outcomes in Research Interdisciplinary Working Groups: The American Academy of Neurology affirms the value of this guideline as an educational tool for neurologists. Circulation 2007; 115(20):e478-e534.
47. Guidelines for management of ischaemic stroke and transient ischaemic attack 2008. Cerebrovasc Dis 2008; 25(5):457-507.

48. Tikhonoff V, Zhang H, Richart T, Staessen JA. Blood pressure as a prognostic factor after acute stroke. Lancet Neurol 2009; 8(10):938-948.

49. Anderson CS, Huang Y, Wang JG et al. Intensive blood pressure reduction in acute cerebral haemorrhage trial (INTERACT): a randomised pilot trial. Lancet Neurol 2008; 7(5):391-399.

50. Broderick J, Connolly S, Feldmann E et al. Guidelines for the management of spontaneous intracerebral hemorrhage in adults: 2007 update: a guideline from the American Heart Association/American Stroke Association Stroke Council, High Blood Pressure Research Council, and the Quality of Care and Outcomes in Research Interdisciplinary Working Group. Circulation 2007; 116(16):e391-e413.

51. Pontes-Neto OM, Oliveira-Filho J, Valiente R et al. [Brazilian guidelines for the manegement of intracerebral hemorrhage]. Arq Neuropsiquiatr 2009; 67(3B):940-950. 